\title{
NÄKÖKULMIA POLIITIKON VIESTINTÄOSAAMISEEN
}

\author{
Minna Finstad, FM \\ Pubeopin laitos, Tampereen yliopisto
}

Pekka Isotalus, FT

Pubeopin laitos, Tampereen yliopisto

\section{TIIVISTELMÄ}

Artikkelissa tarkastellaan teoreettisesti poliitikkojen viestintäosaamista. Aihetta lähestytään kolmen eri näkökulman kautta. Ensimmäinen ja konkreettisin tarkastelunäkökulma on yksilötaso eli viestintäosaamisen merkitys poliitikon henkilökohtaisen viestinnällisen toimintakyvyn ja menestyksen kannalta. Poliitikon näkökulmasta viestintäosaaminen edistää henkilökohtaisten päämäärien saavuttamista, kuten vaalimenestystä tai suotuisan imagon luomista ja ylläpitämistä. Toinen tarkastelutaso on poliitikon viestintäosaamisen merkitys politikkojen ja kansalaisten välisen vuorovaikutuksen kannalta. Politiikka on jatkuvaa yhteistoimintaa, jossa yhdessä luodaan merkityksiä sekä neuvotellaan ja asetetaan päämääriä, joita kohti pyritään. Tähän tasoon keskeisesti liittyviä viestintäosaamisen osa-alueita ovat esimerkiksi kyky muodostaa vuorovaikutteinen suhde kansalaisiin sekä kuunnella ja havainnoida yhteiskunnassa tapahtuvia ajankohtaisia asioita. Lisäksi pohdimme poliitikon roolia yhteiskunnallisena auktoriteettina ja tarkastelemme poliitikon viestintäosaamisen käsitettä etiikan ja demokratian toteutumisen näkökulmasta. Poliitikko on johtaja ja suunnannäyttäjä, jonka on pystyttävä valitsemaan ja muotoilemaan yhteiskunnallisesti arvokkaita päämääriä. Tämän takia muun muassa johtamisviestinnän ja viestinnän eettisten periaatteiden hallinnan taidot liittyvät läheisesti poliitikon viestintäkompetenssiin. Poliitikko yhteiskunnallisena auktoriteettina säätelee sosiaalista todellisuuttamme ja viestinnällään vaikuttaa paljolti siihen, millaiseksi yhteinen tulevaisuutemme muotoutuu.

Asiasanat: osaaminen, politiikka, pubeviestintä, viestintä

\section{JohDANTo}

Politiikan ja viestinnän kiinteä yhteys on tunnustettu jo 2300 vuoden ajan. Antiikin retoriikka käsittelee laaja-alaisesti poliittisia puheita, ja puhetaito katsotaan poliittisen osaamisen keskeiseksi osa-alueeksi. Poliitikkojen viestintäosaamisen merkitys ei myöskään ole vähentynyt noista ajoista, sillä poliitikko tekee yhä työtään pääasiassa viestimällä muiden kanssa. Puheiden pitämisen taidon lisäksi poliitikon tulee kuitenkin nykyisin hallita myös monia muita viestintätaitoja. Esimerkiksi nykypäivän medialisoituva politiikka asettaa jat- 
kuvasti uusia haasteita poliitikkojen viestintäosaamiselle.

Politiikkaa voidaan pitää viestinnän välityksellä tapahtuvana monitasoisena sosiaalisena vuorovaikutuksena, jossa viestintään liittyvien tekijöiden hallinnalla on keskeinen rooli. Politiikka on jatkuvaa vuorovaikutusta - keskustelua, neuvottelua ja väittelyä - erilaisten yhteiskunnallisten tahojen ja ryhmittymien välillä, joista jokainen tähtää oman hyvinvointinsa turvaamiseen. Politiikan olemukseen liittyvätkin läheisesti myös kamppailu, valtataistelu, konfliktit ja ristiriidat. Kuten Paloheimo ja Wiberg $(1997,15)$ osuvasti toteavat, politiikka on konfliktien ja yhteistyön jatkuvaa vuorottelua. Weberin mukaan politiikka operoi ihanteellisimmillaan järjestyksen ja epäjärjestyksen välimaastossa ja tasapainottaa eri ihmisryhmittymien välisiä ristiriitaisuuksia (Pekonen 1989, 186).

Tässä artikkelissa lähtökohtanamme on nïn sanottu institutionaalinen määritelmä, jonka mukaan politiikka käsitetään muusta yhteiskunnallisesta toiminnasta erilliseksi toiminnan sektoriksi, jolla on oma toiminnallinen logiikkansa, omat erityiset toimijansa ja omat toiminnan tilansa, kuten puolueet tai eduskunta (esim. Kegley \& Wittkopf 2001; Paloheimo \& Wiberg 1997). Poliitikolla viitataan tässä artikkelissa suomalaisiin kansanedustajiin, ministereihin, europarlamentaarikoihin ja presidenttiin. Näiden korkeassa asemassa olevien poliitikkojen toiminnan tulokset ja seuraukset heijastuvat erityisen vahvasti koko yhteiskunnan tasolla ja tämän vuoksi myös kompetenssivaatimukset ovat luonnollisesti suuremmat.

Poliitikkojen viestintäosaamiseen liittyvät läheisesti myös vallan ja etiikan käsitteet. Weber (1949) on todennut politiikan olevan pohjimmiltaan viestinnän välityksellä tapahtuvaa yhteisten merkitysten luomista, joka kytkeytyy läheisesti vallan käyttöön sekä toisaalta myös arvoihin ja etiikkaan (Pekonen 1989, 120). Poliitikot yhteiskunnallisina auktoriteetteina tai johtajina viestinnällään jatkuvasti luovat ja säätelevät sosiaalista todellisuuttamme. Suhteessa tavallisiin kansalaisiin poliitikoilla on enemmän valtaa hallita, muotoilla ja jopa manipuloida yhteiskunnallista toimintaa ja todellisuutta. Samanaikaisesti poliitikoilla on korkean valta-asemansa takia myös suuri eettinen vastuu teoistaan ja viestintäkäyttäytymisestään kansalaisia ja muita sidosryhmïä kohtaan.

Poliitikon ammatti poikkeaa muista vanhoista, perinteisistä yhteiskunnallisista professioista, kuten läääri, pappi, lakimies tai opettaja, ainakin sïnä mielessä, että-poliitikoksi yleensä valitaan demokraattisella vaalilla. Poliitikon ammattiin ei siis ole olemassa muodollista koulutusta, vaan ammattiin valinnan kriteerinä on menestys vaaleissa. Näin ollen poliitikon ammattia ei voida suoraan rinnastaa muihin perinteisiin professioihin. Poliitikoksi pääsemisen edellytyksenä on kyky saada puolelleen äänestäjiä ja tukijoita eikä virallinen, standardisoitu, muodollinen koulutus. Palosen $(2002,65)$ mukaan poliitikon pätevyyden määrittelystä haastavaa ja vaikeaa tekee juuri se, että poliitikko ei ole "oikea" ammatti. Poliittinen pätevyys ei hänen mukaansa välttämättä ole 
tutkintojen, tiedon, asiantuntemuksen tai edes tieteen tuottamaa pätevyyttä.

Tarkastelemme tässä artikkelissa teoreettisesti poliitikon viestintäosaamisen erilaisia merkitysulottuvuuksia. Lähestymme aihetta kolmen näkökulman kautta. Ensin pyrimme määrittelemään viestintäosaamisen käsitettä yksilöta solla sekä tunnistamaan ja nimeämään poliitikkojen ammattitaidon kannalta keskeisiä osaamisen osatekijöitä.

Toiseksi pohdimme politiikkaa ja poliitikon ammattia vuorovaikutuksen näkökulmasta. Tarkoituksenamme on osoittaa, että poliitikon ammattia voidaan kutsua vuorovaikutusammatiksi.

Kolmanneksi laajennamme tarkastelunäkökulmaa ja pohdimme poliitikon roolia yhteiskunnallisena auktoriteettina sekä tarkastelemme viestintäkompetenssin käsitettä etiikan sekä demokratian toteutumisen näkökulmasta. Tarkoituksenamme on valottaa viestintä- ja vuorovaikutusosaamisen merkitystä poliitikolle sekä osoittaa, kuinka suuri, monitasoinen ja kokonaisvaltainen rooli viestinnällä on poliitikon ammatissa.

\section{VIESTINTÄOSAAMISEN KÄSITE LÄHTÖKOHTANA}

Valkosen $(2003,26)$ sanoin "viestintäosaaminen tarkoittaa tietoa tehokkaasta ja tarkoituksenmukaisesta viestintäkäyttäytymisestä, motivaatiota ja taitoa toimia viestintätilanteissa tavalla, jota viestintään osallistuvat pitävät tehokkaana ja tarkoituksenmukaisena, taitoa ennakoida, suunnitella, säädellä ja arvioida viestintäkäyttäytymistä sekä sellaisten viestinnän eettisten periaatteiden noudattamista, jotka eivät vaaranna viestintäsuhteita eivätkä loukkaa toisia osapuolia." Valkosen mukaan tehokkuus ja tarkoituksenmukaisuus ovat ensisijaisia viestintäosaamisen arvioinnin kriteereitä. Määritelmä toimii hyvänä lähtökohtana, kun aletaan hahmotella seikkaperäisempää kuvaa poliitikon viestintäosaamisen ulottuvuuksista. Silti se ei sellaisenaan välttämättä riitä tarpeeksi kattavasti kuvaamaan viestintäosaamisen käsitteeseen liittyvää merkitysten kirjoa.

Käsitteenä viestintäosaaminen on hyvin moniselitteinen ja ehkä myös jossain määrin vaikeasti hahmotettava ilmiö. Viestintäosaamista on pyritty kuvaamaan ja jaottelemaan hyvin erilaisista näkökulmista ja lähtökohdista. Viestintätieteiden ohella viestintäosaamista on tarkasteltu myös monien muiden tieteenalojen, kuten kasvatustieteen, sosiologian, sosiaalipsykologian ja psykologian näkökulmasta. 'Teoreettista pohjaa viestintäosaamisen tutkimukselle ovat antaneet muun muassa kielitieteelliset, erityisesti sosiolingvistiset näkemykset kommunikatiivisesta kompetenssista. Lähtökohtien moninaisuuden ja käsitteiden epämääräisyyden takia viestintäosaamisen tutkimukselle on leimallista pirstoutuneisuus, laaja-alaisuus ja hahmottomuus. Myöskään puheviestinnän alalla ei ole muodostunut yhtenäistä viestintäosaamisen tutkimusparadigmaa. (Valkonen 2003, 26.) 
Myös filosofiset ja eettiset kysymykset liittyvät läheisesti viestintäosaamisen käsitteen tarkasteluun. Eräs tunnettu viestintäosaamisen eettis-filosofista ulottuvuutta pohtinut vaikuttaja on Habermas (1987). Hänen keskeisimpiä kysymyksenasettelujaan ovat muun muassa, millaista on ideaali diskurssi kulloisessakin yhteiskunnassa ja millaista osaamista siihen osallistuvilla tulisi olla (Valkonen 2003, 29).

Viestintäosaamisen käsitteen vaikea märäriteltävyys herättää monia tutkimuksellisesti künnostavia kysymyksiä ja motivoi analysoimaan teoreettisesti käsitteen eri merkitysulottuvuuksia. Pohtimisen arvoista olisi esimerkiksi osaavan toiminnan tarkempi määritteleminen: millä perusteella voidaan teoreettisesti erottaa osaava toiminta osaamattomasta, taitamattomasta toiminnasta. Myös viestinnän kokonaisvaltaisuus on yksi haaste viestintäosaamisen tutkimukselle. Jos kaikenlainen inhimillinen käyttäytyminen kuten teot ja sanaton viestintä luetaan merkityksiä välittäväksi viestinnäksi, sisältyy viestintäkäyttäytymiseen tällöin poikkeuksetta aina myös tiedostamaton puolensa. Tärkeitä kysymyksiä ovat esimerkiksi, mikä on tiedostamisen osuus, kun pyritään määrittelemään osaavaa viestintäkäyttäytymistä ja voiko ihminen ylipäätään tulla tietoiseksi kaikesta viestinnästään ja sen seurauksista. Tällaiset kysymylksenasettelut edellyttävät aina myös filosofisen lähestymistavan mukaan ottamista. Myös monitieteiset lähestymistavat sopisivat varmasti luontevasti aihepiirin entistä monipuolisemmalle hahmottamiselle ja saattavat parhaimmillaan edistää erilaisten tutkimuksellisten lähtökohtien välistä vuoropuhelua. Tässä artikkelissa viestintäosaamista tarkastellaan politiikan kontekstissa ja tarkoituksena on ymmärtää poliitikon viestintäosaamista yksilön toimintakyvyn kannalta sekä liittää yksilötason tarkastelu osaksi laajempaa yhteiskunnallista, politiikan olemusta ja päämääriä koskevaa näkökulmaa.

Puheviestinnän näkökulmasta viestintäosaamista tutkinut Kostiainen (2003, 246-248) korostaa, että viestintäosaamisen tutkimuksessa olennaista ei niinkään ole määritellä uusia taitoja, vaan vähintään yhtä tärkeää on pohtia viestintäosaamisen uusia käyttöyhteyksiä sekä etenkin pyrkiä antamaan viestinnälle uusia merkityksiä ja jäsennyksiä erilaisissa konteksteissa. Tässä artikkelissa tarkoituksenamme on luoda teoreettinen jäsennys viestintäosaamisen funktioista ja merkitysulottuvuuksista politiikassa. Tämän uskomme rikastavan viestintäosaamista koskevaa ymmärrystä käsitteellisellä tasolla sekä kirkastavan monella tapaa viestinnän ja politiikan välistä tiivistä yhteyttä. Tällaisen tarkastelu saattaa myös tarjota aineksia puheviestintätieteen ja muiden tieteenalojen, kuten politiikan ja viestinnän välisten yhteyksien löytämiselle. Uskomme, että politiikka ja poliitikkojen viestintäosaaminen tutkimuskohteena tarjoavat juuri tällaisen hedelmällisen sekä yhteiskunnallisesti tärkeän mahdollisuuden laajentaa viestintäkompetenssin tutkimusta yksilötasolta kohti laajempaa, yhteisöllisempää tarkastelunäkökulmaa. 


\section{䇣 Politikon viestintäosaAminen YKSILÖLLISEN Ä RESURSSINA}

Antiikin Kreikan demokraattisissa kaupunkivaltioissa julkinen keskustelu oli keskeisessä asemassa. Saadakseen tahtonsa läpi poliitikoille ei riittänyt asemaan, syntyperään tai väkivaltaan vetoaminen, vaan keskustelun muut osapuolet oli jollakin tavalla vakuutettava omasta pätevyydestä. (Sihvola 1997,193.) Poliitikoksi pääsy ja poliittisen uran luominen edellyttivät siis jo antiikin Kreikassa monipuolista viestintäosaamista.

Varhaisimmat pyrkimykset määritellä teoreettisesti poliitikolta vaadittavaa viestintäosaamista löytyvät Aristoteleen retoriikasta (Valkonen 2003, 25). Aristoteles (1997) on eritellyt yksityiskohtaisesti, millaista puhetaitoa tai viestintäosaamista taitavalta poliitikolta vaaditaan, ja pyrkinyt analysoimaan perusteellisesti vakuuttavan poliittisen puheen osatekijöitä ja edellytyksiä. Hän on luonut myös kuuluisaksi tulleen kolmijakonsa hyvälle puhujalle ominaisista vakuuttamisen välineistä, joita ovat luonteeseen (ethos), tunteisiin (pathos) ja argumentteihin (logos) liittyvät puheen elementit. Aristoteles käsittelee asiaa siis lähinnä yksittäisen puhujan näkökulmasta.

Myös uudemmassa, etenkin yhdysvaltalaisessa poliittista viestintäosaamista käsittelevässä kirjallisuudessa korostuu silmiinpistävästi yksilönäkökulma. Viestintäosaaminen käsitetään yksilön resurssina, jonka avulla on mahdollista maksimoida oma poliittinen menestys. Viestintäkompetenssi nähdään usein yksilöllisenä ominaisuutena, jonka avulla poliitikko voi tuloksellisesti saavuttaa henkilökohtaiset tavoitteensa. Poliitikkojen viestintäosaamista koskeva teoreettinen tutkimus on melko vähäistä. Sen sijaan kvantitatiiviset, yksittäisten muuttujien suhdetta tarkastelevat tutkimukset ovat hyvin yleisiä. Yhdysvaltalaisessa tutkimuksessa on keskitytty lähes yksinomaan erilaisiin poliittisen viestinnän osakonteksteihin; media, vaalit, viestintäteknologia ja poliittiset väittelyt ovat esimerkkejä niistä melko tarkkarajaisista osa-alueista, joissa poliittisen viestinnän tutkimus on ollut erityisen runsasta (esim. Kaid 2004; Mancini \& Swanson 1996).

Yksilön viestintäosaamista voidaan pitää keskeisenä poliittista menestystä selittävänä tekijänä. Poliitikon ammatissa tulokset ovat usein tiiviisti sidoksissa kykyyn vaikuttaa ja vakuuttaa kuulijat ja saada heidät pitämään itsestään. Kaikenlainen poliittinen toiminta, niin käytännön työ kuin julkinen edustaminenkin, tapahtuu ennen kaikkea viestinnän avulla. Politiikka on luonteeltaan tavoitteellista viestintää, eräänlaista jatkuvaa neuvottelua ja päätöksentekoa vallanpitäjien, kansalaisten sekä muiden sidosryhmien välillä. Menestys vaaleissa riippuu siitä, millaisia mielikuvia poliitikko pystyy viestintänsä ja vuorovaikutustyylinsä avulla itsestään välittämään. Kyky herättää äänestäjien kiinnostus ja miellyttää heitä on tärkeää, kun pyritään hankkimaan tukijoita ja äänestäjiä.

Monet nykypäivälle tyypilliset yhteiskunnalliset kehityslinjat asettavat omat 
haasteensa poliitikon viestintäosaamiselle. Yksi tällainen kehityslinja on median aseman korostuminen poliittisessa toiminnassa. Median valtakaudella mediaosaaminen on jokaisen poliitikon viestintäosaamisen keskeinen osatekijä. Koska yhä suurempi osa politiikasta tapahtuu tiedotusvälineiden välityksellä, ovat suorat, välittömät kontaktit politiikkaan osallistuvien kesken vähentyneet. Mediasta onkin tullut äänestäjän ja polititkon vuorovaikutuksen keskeisin välikappale (Isotalus 2001). Onnistunut viestintä edellyttää poliitikolta sïs kattavaa mediaosaamista eli kykyä säädellä, ymmärtää ja hyödyntää median ominaispiirteitä oman viestinnän tukena parhaalla mahdollisella tavalla. Selkeä esimerkki mediaosaamisen merkityksestä politiikassa on, että useiden puolueiden puheenjohtajien valinnassa mediaosaamista on käytetty argumenttina puheenjohtajaehdokkaan puolesta. Erityisesti on korostettu televisioesiintymisen merkitystä. Televisio asettaakin esiintymiselle erityisiä vaatimuksia (esim. Isotalus 2000). Haastavaa poliitikolle onkin esiintyä televisioon sopivalla tavalla ja antaa itsestään kuva samanaikaisesti sekä luotettavana ja ammattitaitoisena että mukavana ja äänestäjien etuja ajattelevana henkilönä.

Lisäksi Suomen poliittisessa järjestelmässä, jossa yksilöt kilpailevat äänistä, tunnettuus on yhä tärkeämpää poliitikoille. Tunnettuutta saavuttaakseen poliitikon on osattava hyödyntää mediaa oikealla tavalla ja usein toimittava sen ehdoilla. Joidenkin näkemysten mukaan julkisuudesta ja tunnettuudesta on kuitenkin kehittynyt nykypäivän poliitikolle eräänlainen itseisarvo, jolloin tärkeät asiakysymykset usein saattavat hautautua varsin itsekkäiden motiivien alle (ks. Cowen \& Sutter 2000).

Fragmentoituneessa, monimutkaistuneessa ja professionalisoituneessa tietoyhteiskunnassa poliitikoilta edellytetään myös korkeatasoista asiantuntemusta. Toisin sanoen asiat, joita poliitikko joutuu käsittelemään, ovat yhä monimutkaisempia ja vaikeampia. Poliitikolta edellytettävää asiantuntemusta voitaisiin kuvailla yhteiskunnan toimintaa koskevaksi kokonaisvaltaiseksi ymmärrykseksi, joka mahdollistaa harkittujen ja pitkälle tulevaisuuteen suuntautuvien päätösten ja ratkaisujen tekemisen sekä samalla myös kyvyksi muotoilla viestinnän monimutkaiset sisällöt ymmärrettävästi kohdeyleisön mukaan. Asiantuntemuskin on siis sidoksissa viestintäosaamiseen.

Modernissa tietoyhteiskunnassa myös viestintäteknologiaosaaminen eli kyky välittää, luoda ja muokata tietoa teknologiavälitteisesti on yksi poliitikon viestintäosaamisen osatekijä. Lisäksi kansainvälistyvässä maailmassa kulttuurienvälisen viestintäosaamisen ja kielitaidon merkitys on poliitikon viestintäosaamisen kannalta tärkeä. Nämä mahdollistavat vuorovaikutuksen monikulttuurisissa ryhmissä sekä edistävät arvokkaiden kansainvälisten kontaktien syntymistä.

Poliitikon viestintäosaamisen kannalta keskeisiä konteksteja ovat myös interpersonaalisen ja ryhmätason vuorovaikutustilanteet. Interpersonaalisen tason vuorovaikutusosaamiisen osatekijöitä ovat ainakin vuorovaikutustilanteen hallin- 
taan liittyvä osaaminen sekä suhteiden luomiseen ja ylläpitämiseen liittyvät taidot eli relationaalinen kompetenssi. Rybmäriestintäkompetenssi vuorostaan koostuu useista yksittäisistä taitoalueista, joita ovat muun muassa perustelutaito, kuuntelutaito, palautteen antamisen ja vastaanottamisen taidot, kyky käsitellä asiaa monipuolisesti, kyky ylläpitää vuorovaikutus ja säilyttää tehtävän suorittamisen kannalta miellyttävä ilmapiïri (Valkonen 2003, 119-122). Lisäksi tärkeää on neuvottelu-, konflikti- ja puolustautumistilanteisiin liittyvä viestintäosaaminen.

Aikaisemmalle poliitikon viestintäosaamista käsittelevälle tutkimukselle tyypillinen yksilön viestinnällistä toimintakykyä korostava lähtökohta voidaan nähdä samanaikaisesti sekä hyödyllisenä ja tarkoituksenmukaisena että toisaalta myös rajallisena näkökulmana. Poliitikon ammattitaidon jäsentäminen yksilön viestinnällisen osaamisen näkökulmasta on luontevaa, ja se konkretisoi hyvin viestintäosaamisen olemusta ja piirteitä erilaisissa poliittisen viestinnän tilanteissa ja osakonteksteissa. Toisaalta tällainen puhtaasti yksilökeskeinen tarkastelunäkökulma saattaa sellaisenaan olla hieman yksipuolinen ja estää näkemästä viestinnän yhteyksiä yksilötasoa laajempiin yhteyksiin.

Viestintä ja sosiaalinen vuorovaikutus muodostuvat useiden toimijoiden yhteisvaikutuksesta, usein ennustamattomasti ja sattumanvaraisesti erilaisten tilanteiden mukaan. Yksilön viestintäosaamisen näkökulma ei siis välttämättä yksinään riitä selittämään tai tekemään ymmärrettäväksi erilaisten vuorovaikutustilanteiden taustalla vaikuttavia tekijöitä. Kokonaisvaltainen ymmärrys viestintätilanteiden laadusta ja tuloksista politiikassa edellyttää myös yksilönäkökulmaa laajempia lähestymistapoja. Esimerkiksi ryhmädynamiikkaan, valtaasetelmiin, kulttuurieroihin sekä viestinnälle asetettuihin tavoitteisiin liittyvät seikat vaikuttavat keskeisesti siihen, millaiseksi viestintätilanteet politiikassa kehittyvät ja mikä on yksilön osaamisen merkitys koko tilanteen kehittymisen kannalta. Lisäksi laajemmat aikakauteen ja kulttuuriin sidoksissa olevat tekijät vaikuttavat aina käsityksiin siitä, millainen viestintäkäyttäytyminen voidaan ylipäätään luokitella osaavaksi tai tavoiteltavaksi.

Mielestämme yksilötasoa laaja-alaisempi teoreettinen jäsentely on tärkeä edellytys ja lähtökohta politiikan ja viestinnän suhteen ymmärtämiseksi. Poliitikkojen viestintäosaamisen vaikutukset ja tulokset eivät rajoitu ainoastaan yksilön viestintätavoitteiden tai menestyksen tasolle vaan ulottuvat aina yhteiskunnan tasolla tapahtuvaan sosiaaliseen toimintaan asti.

\section{Politikon viestintä̈osaAminen}

POLIITIKKOJEN JA KANSALAISTEN VÄLISEN VUOROVAIKUTUKSEN EDELLYTYKSENÄ

Politiikka perustuu ihmisten kanssakäymiseen, jossa toiminnan tulokset määräytyvät yhteistyössä, usean toimijan välisessä aktiivisessa vuorovaikutukses- 
sa. Omalla viestintäkäyttäytymisellään yksilöt vaikuttavat lukemattomin tavoin toistensa käsityksiin, asenteisiin ja tekoihin. Vuorovaikutus synnyttää yhteisesti jaettuja uusia, ainutlaatuisia ja usein luonteeltaan ennakoimattomia merkityksiä ja tapahtumakulkuja, joita ei välttämättä ole mahdollista ymmärtää ainoastaan yksilön viestintätavoitteiden näkökulmasta käsin. Politiikka on monimuotoinen, monensuuntaisten sosiaalisten suhteiden verkosto, jossa eri toimijoiden välillä vallitsee jatkuva keskinäinen rïppuvuus.

Viestintätieteellisestä näkökulmasta on kiinnostavaa tarkastella poliitikkojen ja kansalaisten välistä suhdetta vuorovaikutussuhteena. Poliitikkojen ja kansalaisten väliset suhteet eivät välttämättä ole suoraan rinnastettavissa perinteisiin interpersonaalisiin vuorovaikutussuhteisiin, vaan ne ovat usein välillisempiä ja monimutkaisempia. Silti poliitikkojen ja kansalaisten välinen suhde on kaksisuuntainen sïnä mielessä, että poliitikot saavat toimintansa oikeutuksen äänestäviltä kansalaisilta, jotka vastavuoroisesti odottavat poliitikon kantavan huolta heille tärkeistä asioista. Vaikka poliitikkojen ja kansalaisten väliset suhteet ovat usein melko abstraktit ja välillisemmät kuin esimerkiksi poliitikkojen keskinäiset suhteet, ovat kansalaiset silti vuorovaikutussuhteen toinen osapuoli, jonka mielipiteiden, tavoitteiden ja toiveiden pitäisi olla yhtä lailla merkityksellisiä yhteiskunnallisen päätöksenteon kannalta.

Poliitikkojen ja kansalaisten välillä vallitsee siis selkeän vuorovaikutteinen riippuvuussuhde, jossa yhteistyöllä ja luottamuksella on keskeinen rooli. Parhaimmillaan viestintä poliitikkojen ja kansalaisten välillä on luonteeltaan toisen osapuolen näkökulman huomioivaa, vuorovaikutteista ja yhteisymmärrykseen tähtäävää yhteistoimintaa. Yhteistyön merkitys viestinnän onnistumisen kannalta on tunnustettu myös yleisemmällä tasolla. Yhteistyön periaatteen mukaan inhimillistä viestintää ja vuorovaikutusta jäsentää pyrkimys yhteistyöhön ja yhteisymmärrylkseen. Vuorovaikutuksen ongelmat voivat yhteistyön periaatteen näkökulmasta johtua siitä, että toinen tai molemmat osapuolet rikkovat viestintää ohjaavaa yhteistyön ja vastavuoroisuuden periaatetta (Littlejohn 2002, 76-87).

Tätä ajatusta voidaan soveltaa myös tarkasteltaessa kansalaisen ja poliitikon välistä vuorovaikutussuhdetta. Esimerkiksi äänestäessään kansalainen antaa äänensä eli luottamuksensa ja hyväksyntänsä poliitikon toiminnalle. Jotta yhteisymmärrys yhteistyön periaatteen mukaisesti saavutettaisiin, poliitikon tulee vastavuoroisesti toimia äänestäjän luottamuksen ja hyväksynnän ylläpitämiseksi. Setälän $(2003,267)$ mukaan koko demokraattisen vaalin perustana on ajatus siitä, että äänestäjät voivat luottaa, että heidän valitsemansa edustajat toimivat toivotulla tavalla siitä huolimatta, etteivät he pysty jatkuvasti kontrolloimaan näiden toimintaa. Jos poliitikot Setälää mukaillen eivät osoittaudu luottamuksen arvoisiksi, äänestäjät voivat ilmaista epäluottamuksensa monin tavoin, kuten muuttamalla äänestyskäyttäytymistään. Setälän mukaan luottamus on myös 
yleisemmällä tasolla erityisen keskeinen tekijä kaikenlaisen poliittisen toiminnan kannalta.

Myöskään vaalikampanjaviestintää ei ole syytä tarkastella yksipuolisesti pelkästään yksisuuntaisena viestintänä poliitikolta äänestäjille. Vähintäänkin yhtä paljon merkitystä on viestinnän toisen osapuolen, äänestäjän tarpeilla, toiveilla, odotuksilla ja tavoitteilla. Demokraattista vaalia edeltävä toiminta on myös hyvin konkreettisesti kaksisuuntaista vuorovaikutusta äänestäjän ja poliitikon välillä; onnistunut vaalikampanjaviestintä saa äänestäjissä aikaan motivaation vastavuoroiseen toimintaan eli antamaan äänensä, tukensa ja kannatuksensa luotettavimmaksi ja pätevimmäksi katsomalleen henkilölle.

Viimeaikaisessa julkisessa keskustelussa on useasti noussut esiin huolestuneita kannanottoja poliitikkojen ja kansalaisten välisten suhteiden heikkenemisestä sekä kansalaisten muuttuvasta asemasta nykyisessä postmodernissa yhteiskunnassa. Esimerkiksi laskeva äänestysaktiivisuus, lisääntyvä tyytymättömyys, epäluottamus sekä etenkin nuorten keskuudessa välinpitämättömyys poliitikkojen toimintaa kohtaan on usein nähty vakaviksi uhiksi demokratialle. Nämä muutokset voitaisiin myös nähdä seurauksina poliitikkojen ja kansalaisten välisen vuorovaikutussuhteen ongelmista.

Suomessa äänestysaktiivisuuden taso on laskenut useamman vuosikymmenen ajan. Suomen pudotus on ollut etenkin muihin pohjoismaihin verrattuna poikkeuksellisen jyrkkää ja edennyt pidemmälle (Martikainen \& Wass 2002, 18-19). Erityisesti nuorten aikuisten kiinnostus vaalien välityksellä tapahtuvaa poliittista osallistumista kohtaan on vähentynyt. Tutkimukset osoittavat, että esimerkiksi kuntatasolla kansalaisten ja poliitikkojen välinen vuorovaikutus on puutteellista ja että erityisesti nuorten käsityksiä ei huomioida tarpeeksi (ks. Oulasvirta 2001, 35). Martikaisen ja Wassin (2002) mukaan nuorten alhainen äänestysaktiivisuus on vakava tosiseikka ja kysymystä äänestysaktiivisuuden lisäämisestä ei voida ratkaista "vippaskonsteilla", kuten mahdollisuudella äänestää Internetin välityksellä. Demokratian jatkuvuuden kannalta äänestysaktiivisuuden laskeminen on vakava ongelma.

Näiden huolestuttavien tutkimustulosten valossa keskeinen kysymys on, miten poliitikkojen ja kansalaisten välistä vuorovaikutusta voitaisiin parantaa ja millaiset tekijät ylipäätään auttavat luottamuksellisten vuorovaikutussuhteiden syntyä poliittisen eliitin ja massan välillä. Äänestysaktiivisuuden lisäämiseksi ja demokratian kehittämiseksi on ehdotettu muun muassa erilaisten asiakaspalautejärjestelmien kehittämistä, laajempaa tiedottamista ja entistä tehokkaampaa tietoverkkojen hyödyntämistä (Oulasvirta 2001). Tällaiset keinot ovat kuitenkin pohjimmiltaan vain teknisiä ratkaisuita tiedon tehokkaaseen siirtämiseen. Jos vallanpitäjien asenne äänestäjää kohtaan on välinpitämätön ja toimintaa ohjaavat henkilökohtaiset motiivit, ei erilaisten teknisten apuvälineiden käyttö viestinnän tehostamiseksi välttämättä pureudu poliitikkojen ja 
äänestäjien välisen vuorovaikutuksen todellisiin ongelmiin. Putnam (1993) on tarkastellut empiirisesti, millaiset tekijät selittävät demokraattisten instituutioiden menestystä. Keskeisimpiä toimivalle demokratialle tyypillisiä piirteitä ovat hänen mukaansa yhteistyö, vuorovaikutteisuus, yhteisymmärrys sekä kansalaisten vapaaehtoinen, aktiivinen osallistuminen, joihin hän viittaa tunnetuksi tekemällään käsitteellä "sosiaalinen pääoma". Putnam tarkastelee politiikkaa sosiaalisena vuorovaikutuksena, jonka ytimessä ovat luottamus ja yhteisöllisyys.

Hyvä lähtökohta on lähestyä poliitikkojen ja kansalaisten väliseen suhteeseen liittyviä ongelmia poliittisen kompetenssin - erityisesti viestintäkompetenssin - näkökulmasta. Tärkeä osa poliitikon ammattiosaamista on vastuu vuorovaikutusprosessin toista osapuolta eli kansalaista kohtaan. Lewinin (1970) mukaan nimenomaan poliitikkojen vastuulla on stimuloida vuorovaikutuksen syntymistä ja rohkaista massan osallistumista päätöksentekoon. Mazzolenin (2000) mukaan poliitikolta edellytetään kykyä esittää asiat kïnnostavasti ja ennen kaikkea viestintänsä välityksellä rohkaista kansalaisia ilmaisemaan itseään poliittisissa prosesseissa. Kuten Martikainen ja Wass (2002, 26-29) osuvasti toteavat, politiikan tuloksellisuuden ja ennen kaikkea legimiteetin ylläpitämisen kannalta on ensiarvoisen tärkeää, että kansalaiset haluavat ja kokevat voivansa vaikuttaa päätöksentekoon. Kyseisten tutkijoiden mukaan tällaista vaikutusmahdollisuutta voidaan pitää eräänlaisena itseisarvona, joka muodostaa länsimaisen demokratian ytimen. Näin ollen poliitikon kyky rohkaista kansalaisia aktiiviseen vuorovaikutukseen nousee poliitikolta edellytettävän viestintäosaamisen keskiöön. Vuorovaikutusosaamista voitaneen pitää jopa poliitikon ammatin ydinpätevyytenä, jonka avulla saadaan aikaiseksi ja ylläpidetään tuloksellista vuorovaikutusta kansalaisten ja muiden sidosryhmien kanssa.

Tällaista poliitikolta edellytettävää vuorovaikutustaitoa voitaisiin konkreettisemmin kuvailla kyvyksi havainnoida, kuunnella ja ymmärtää kansalaisten näkökulmasta tärkeitä asioita. Kuuntelu- ja havainnointitaito eivät rajoitu ainoastaan informaatiosisällön kuuntelun tasolle, vaan aivan yhtä tärkeää on ymmärtää ja arvioida emotionaalisia merkityksiä ja erilaisia vivahteita, jotka usein välittävät tietoa pintaa syvemmistä motiiveista, intentioista ja tarkoitusperistä. Kuuntelutaidon avulla on mahdollista ennakoida muiden tekoja ja näin ollen saavuttaa syvempi ymmärrys viestintätilanteista sekä lisätä niiden hallittavuutta ja ennakoitavuutta. Samalla mahdollisuudet todelliseen yhteistyöhön ja yhteisymmärryksen saavuttamiseen paranevat.

Poliitikolta edellytettävä kuuntelutaito tai laajemmin vastaanottoon ja evaluointiin liittyvä kompetenssi viittaa myös kykyyn havainnoida, tulkita ja huomioida yhteiskunnallisen toiminnan kannalta olennaisia ja tärkeitä ongelmakohtia ja hoitoa vaativia asioita. Laajemmassa merkityksessä kuuntelu ja havainnointi voi kohdistua niin yksilöiden ja erilaisten sidosryhmien tavoitteisiin ja tarpeisiin kuin myös yhteiskunnallisen tason joukkotiedotuksessa käsiteltäviin tärkeisïn 
puheenaiheisiin. Keskeistä poliitikon kuuntelutaidon ja laajemman osaamisen kannalta on erityisesti kyky ymmärtää muiden poliittisiin prosesseihin osallistuvien tavoitteita, päämääriä ja tarpeita sekä tehdä niiden pohjalta harkittuja poliittisia päätöksiä, joissa otetaan huomioon henkilökohtaisia intressejä laajempi yhteinen etu. Poliittinen viestintä ei siis ole vain poliitikoilta kansalaisille suuntautuvaa yksisuuntaista tiedottamista tai poliitikkojen keskinäistä neuvottelua, ryhmätyötä ja konfliktinhallintaa vaan huomattavasti moniulotteisempi, vuorovaikutteinen prosessi, joka parhaimmillaan saa alkunsa kansalaisille tärkeistä asioista. Kilpailun ja henkilökohtaisen menestyksen lisäksi politiikassa hyvin keskeistä on yhteisymmärrystä lisäävä keskustelu sekä avoin, ymmärtämään pyrkivä vuorovaikutus kansalaisten kanssa. Tämä toteutunee kuntatasolla jossain määrin paremmin kuin valtakunnallisen politiikan tasolla, mutta erityisen suuri haaste kansalaislähtöinen vaikuttaminen ja avoin vuorovaikutus ovat tällä hetkellä EU-politiikalle.

Poliitikon ammattia voidaan hyvällä syyllä pitää vuorovaikutusammattina, jossa toiminnan tulokset määräytyvät nimenomaan vuorovaikutuksessa ja jossa onnistuminen riippuu hyvin pitkälti viestintään liittyvien tekijöiden hallinnasta. Gerlanderin ja Takalan (2000, 157-158) mukaan tällaisissa vuorovaikutusammateissa onnistuminen riippuu olennaisesti viestinnän ja vuorovaikutuksen toimivuudesta. Poliitikkona toimiminen edellyttää monipuolista viestintäosaamista, vuorovaikutustekijöiden hallintaa sekä ihmisten toiminnan ja sen säätelyn ymmärtämistä. Gerlander ja Takala toteavat, että vuorovaikutusammateissa nimenomaan vuorovaikutus on se kehys, jossa työn tuloksellisuus lopulta määräytyy. Poliitikon ammattia voidaan myös pitää cräänlaisena palveluammattina, jossa tärkeimpänä tavoitteena on asiakkaiden eli äänestäjien palveleminen. Viestinnän tutkimuksen näkökulmasta avoin vuorovaikutus asiakkaiden ja muiden tärkeiden sidosryhmien kanssa on tällöin keskeisin lähtökohta ja edellytys tällaisen palvelusuhteen synnylle.

Viestintä- ja vuorovaikutusosaamisen merkitys poliitikon ammattitaidon kannalta korostuu yhä enemmän nykyisessä tilanteessa, jolle on tyypillistä monentasoiset demokratian toimivuutta uhkaavat, poliitikkojen ja kansalaisten väliseen suhteeseen liittyvät ongelmat. Poliitikon kyky kuunnella, havainnoida, luoda suhteita ja kannustaa kansalaisia aktiiviseen vuorovaikutukseen noussee yhä keskeisemmäksi poliittisen kompetenssin osatekijäksi. Lisääntynyt ymmärrys viestinnän ja vuorovaikutuksen merkityksestä politiikassa voi parhaimmillaan myös auttaa jäsentämään ja kirkastamaan kuvaa niistä pätevyysvaatimuksista, joita poliitikon ammatin vastuullinen ja tuloksellinen hoitaminen edellyttää. Kun tiedostetaan poliitikon ammattitaidon keskeisimmät osatekijät, lienee myös helpompaa pohtia ja löytää käytännön ratkaisumalleja erilaisiin politiikan ongelmiin. Samalla mahdollisuudet kehittää ja jalostaa poliittista ammattipätevyyttä esimerkiksi viestintäkoulutuksen avulla entisestään 
parantuvat. Tätä kautta voidaan parhaimmillaan oppia löytämään kansalaislähtöisempiä, aktiivisempaan osallistumiseen kannustavia poliittisen toiminnan muotoja ja näin vahvistaa demokratian perustaa.

\section{Politikgo yhteiskunnallisena auktoriteettina}

Poliitikkojen viestintä on aina samalla myös vallan käyttöä. Puheviestinnän näkökulmasta vallan käyttö on eräänlainen vuorovaikutuksen muoto, joka ilmenee erilaisissa dialogisissa vuorovaikutustilanteissa interpersonaaliselta tasolta aina yhteiskunnan tasolle saakka (Gerlander 1995). Lähtöoletuksenamme onkin, että poliittinen vallan käyttö toteutuu osaltaan myös aivan mikrotasolla, yksittäisten poliitikkojen viestinnässä. Jokainen korkeassa yhteiskunnallisessa asemassa toimiva poliitikko viestinnällään jatkuvasti määrittelee, muotoilee, säätelee ja manipuloi sosiaalista todellisuuttamme. Näin ollen poliitikot siis käyttävät viestinnällistä valtaa suhteessa tavallisiin kansalaisiin. Viestintäkompetenssinsa avulla poliitikolla on osaltaan mahdollisuus vaikuttaa yhteiskunnassa ilmeneviin vallan käytön tapoihin ja sitä kautta aktiivisesti muokata yhteiskuntaa tietynlaisten ihanteiden mukaiseksi. Tätä kautta politiikka ja poliittinen viestintä ovat myös tiiviisti sidoksissa moraaliin ja etiikkaan, sillä poliitikolla on valta-asemansa takia samalla myös suuri eettinen vastuu omasta viestintäkäyttäytymisestään ja sen seurauksista. Poliittiseen johtajuuteen liittyvä vastuu on erityisen suuri sen takia, että poliitikko saa oikeutuksen toiminnalleen äänestäviltä kansalaisilta, joille hän on myös suoraan vastuussa tekemistään ratkaisuista. Poliitikko siis edustaa kansalaista ja pyrkii huolehtimaan tämän hyvinvoinnista.

Poliittisen johtajan tärkein ase on jo antiikin ajoista lähtien ollut puhetaito, jonka avulla hänen on mahdollista saada kannatusta, ohjata ja johtaa ihmisiä kohti valitsemiaan päämääriä, taistella vastustajia vastaan sekä väitellä ja vakuuttaa muut oman kannan tärkeydestä. Oulasvirran $(2001,30)$ mukaan poliittisen johtajan tulee olla tavallista kansalaista paremmin informoitu asiantuntija, joka aktiivisesti osallistuu ja vaikuttaa kansalaiskeskusteluun. Poliitikon ammattitaidon kannalta keskeisiä johtamisviestinnän osa-alueita ovat muun muassa valtaaseman hankkiminen ja ylläpitäminen, toiminnan suunnan ja konkreettisten tavoitteiden asettaminen, tilanteen ja muiden toimijoiden kannalta tarkoituksenmukaisen vuorovaikutus- ja viestintätyylin löytäminen sekä laaja-alaisempi ymmärrys koko johtamistilanteesta. Taitava poliittinen johtaja kykenee ennen kaikkea itsenäiseen ajatteluun ja arviointiin sekä pystyy ymmärtämään, miten erilaiset tekijät saattavat vaikuttaa omaan ja muiden toimintaan sekä yhteisten tavoitteiden saavuttamiseen.

Poliittiselta johtajalta vaaditaan siis pelisilmää, kykyä luoda toimivia strategioita ja suunnitelmia vastustajien aseman horjuttamiseksi. Usein politiikkaa verrataankin peliin tai kilpailuun; saavuttaakseen johtavan aseman politiikassa henkilön tulee olla älykäs ja rohkea pelaaja, joka ensinnäkin saavuttaa kansa 
laisten tuen, toiseksi menestyy oman puolueensa sisällä, kolmanneksi pystyy toimimaan ja kilpailemaan muiden puolueiden ja ryhmittymien kanssa sekä neljänneksi hallitsee myös mediapelin, eli pystyy hyödyntämään mediaa toimintansa tukena.

Toisaalta poliittisen johtajan tulee myös hallita "pehmeämpiä" osaamisen osa-alueita. Poliitikon tehtävänä ei ole ainoastaan vaikuttaa kansalaismielipiteeseen vaan myös heijastaa äänestäjiensä mielipiteitä (Oulasvirta 2001, 30). Kyky samaistua edustamansa ryhmän tilanteeseen, kuunnella ja huomioida heidän näkemyksiään ja ottaa niitä oman toiminnan lähtökohdiksi on viime kädessä keskeisin tapa, jolla kansan ääni saadaan kuuluville. Poliitikko siis toteuttaa työssään kahdenlaisia tehtäviä; hän ensinnäkin huomioi ja kuuntelee kansalaisten mielipiteitä, ongelmia ja toiveita sekä toisaalta taas pyrkii ohjaamaan ja vaikuttamaan yhteiskunnan toimintaan. Poliittiseen ammattitaitoon sisältyykin selkeästi kaksi erilaista puolta: toisaalta kyky ymmärtää edustamiensa ihmisten toiveita ja pyrkimyksiä sekä toisaalta kyky käyttää valtaa, johtaa ihmisiä, tehdä päätöksiä ja toimia eräänlaisena edelläkävijänä. Poliitikon ammattitaidon kannalta keskeistä on kyky yhdistää omassa toiminnassa joustavasti ja tasapainoisesti nämä hyvin erityyppiset osaamisen osa-alueet, empaattinen kuunteleva myötäeläminen sekä lujatahtoinen johtajuus.

Viestinnän kriittisiä teoreetikoita edustavalla Habermasilla (1984, Littlejohnin 2002, 210-214 mukaan) on tunnettu näkemys viestintäosaamisen ja yhteiskunnallisella tasolla tapahtuvan vallan käytön suhteesta. Hän näkee yksilön kommunikatiivisen kompetenssin yhteiskunnallisen emansipaation, epäoikeudenmukaisesta poliittisesta vallan käytöstä vapautumisen, keskeisimpänä välineenä. Yhteiskunnan jäsenten riittävä kommunikatiivinen kompetenssi takaa mahdollisuuden ideaalin diskurssin toteutumiselle. Ideaali diskurssi on kaikille avoin, emansipatorinen, vapauttava ja uutta luova keskustelutilanne, jossa kaikilla on yhtäläiset oikeudet osallistua. Kuten Fishkin $(1995,40)$ kiteyttää, ideaalissa diskurssissa "kaiklkiin argumentteihin vastataan vapaassa ja tasavertaisessa keskustelussa. Kutakin argumenttia, jonka joku keskustelussa arvioi relevantiksi, kuunnellaan niin pitkään kuin kuka tahansa haluaa. Ihmiset ovat valmiita tarkastelemaan jokaista esitettyä argumenttia täysin objektiivisesti. - -. Ainut voima, jota kysymysten ratkaisemiseen käytetään, on paremman argumentin voima". (Pietilä 2002.) Habermasin (1984) mukaan demokratian ytimenä on sellainen puhuminen, joka koulii kansalaisissa kykyä todelliseen julkiseen ajatteluun ja poliittiseen arviointiin niin, että he pystyisivät hahmottamaan yhteistä tulevaisuutta paremmin yhteisen hyvän pohjalta.

Vaikka näkemystä voidaan pitää idealistisena, tarjoaa se silti mielenkiintoisia ja arvokkaita lähtökohtia viestintäosaamisen merkityksen laajemmalle ymmärtämiselle. Viestintäosaaminen on siis selkeästi yhteydessä myös käsityksiimme hyvästä yhteiskunnasta ja oikeudenmukaisista vallankäytön muo- 
doista. Kehittynyt, korkeatasoinen viestintäosaaminen ei siis ole ainoastaan yksilöllisten tavoitteiden saavuttamisen väline vaan on yhtä lailla yhteydessä koko yhteiskunnan tasolla tapahtuvien vallankäytön tapoihin sekä käsityksiimme oikeasta ja väärästä.

Modernisaatiomurroksen ja globalisaation mukanaan tuomat mutokset niin taloudessa, politiikassa kuin muillakin yhteiskunnallisen toiminnan aloilla ovat synnyttäneet huolestuneita reaktioita demokratian tilasta ja mahdollisuuksista (ks. esim. Cerny 1999; Cowen \& Sutter 2000; Mazzoleni \& Schultz 1999). Globalisaatio kehitysvoimana ja prosessina on hyvin abstrakti ja hallitsematon sekä koskettaa laaja-alaisesti kaikenlaisia yhteiskunnallisia rakenteita ja tasoja. Kuitenkin poliitikot yhteiskunnallisina auktoriteetteina voivat eniten vaikuttaa yhteiskunnassa tapahtuviin muutoksiin ja niiden seurauksiin. Näin ollen vastuu demokratian toimivuudesta kuuluu ensisijaisesti poliitikoille eli demokraattisille johtajille, joilla on korkeasta valta-asemastaan johtuen tavallista kansalaista suuremmat mahdollisuudet vaikuttaa yhteisiin asioihin. Omalla viestintäkäyttäytymisellään poliitikko voi edistää demokratian näkökulmasta oikeudenmukaisen vallankäytön toteutumista ja näin toimia vastuullisena poliittisena johtajana.

Myös etiikka ja arvokäsitykset ovat aina merkittävässä roolissa kaikenlaisessa poliittisessa päätöksenteossa ja keskustelussa. Laajan ja mielenkiintoisen näkemyksen politiikan ja etiikan suhteesta esittää Max Weber (1968). Hänen kokonaisvaltaiset, ajatuksia herättävät pohdintansa sopivat erinomaisesti taustaksi myös tarkasteltaessa nykypäivän poliitikon viestintäosaamista etiikan näkökulmasta. Weberin mukaan politiikka operoi ihanteellisimmillaan nimenomaan arvojen ja etiikan alueella. Politiikan ensisijaisimpana päämääränä on pitää yllä arvokeskustelua sekä saada ihmiset yhdessä pohtimaan ja reflektoimaan sosiaalisesti arvokkaita asioita ja yhteisiä päämääriä.

Weberin (1968) näkemyksestä heijastuu mielenkiintoinen ja järkevä ajatus siitä, että politiikan tehtävä ja yhteisöllinen merkitys on monella tapaa syvälle ulottuvampi ja abstraktimpi kuin esimerkiksi talouselämän. Nimenomaan arvosidonnaisuutta voidaan pitää politiikan erityislaatuna ja poliittista toimintaa keskeisesti määrittävänä ominaispiirteenä. Demokraattisessa politiikassa muotoillaan jatkuvassa vuorovaikutuksessa niitä yhteisiä merkityksiä, arvopäämäärïä ja suuntia, joihin yhteiskuntaa halutaan kehittää ja jotka koetaan tärkeiksi koko yhteisön hyvinvoinnin ja olemassaolon kannalta. Demokratiaa voidaankin pitää ennen kaikkea viestinnällisenä prosessina, jonka muotoutuminen, toteutuminen ja kehittyminen ovat tiiviisti sidoksissa myös yksittäisten poliitikkojen viestintäkompetenssiin.

Yksittäinen poliitikko on jatkuvasti omassa toiminnassaan tekemisissä eettisten kysymysten ja valintojen kanssa. Poliitikon eettisiä valintoja ovat esimerkiksi seuraavat: Onko annetuilla vaalilupauksilla katetta? Paljastetaanko yhteisten pelisääntöjen vastaisesti asioita julkisuuteen oman edun nimissä? Ottaako po- 
liitikko eettisen näkökulman keskusteluun jonkin yksittäisen asiakysymyksen kohdalla? Poliitikon on siis tärkeää tiedostaa roolinsa yhteisen edun ajajana eikä antaa itsekkäiden, omïn valtapyrkimyksiin liittyvien motiivien hämärtää laajempia ihmisryhmiä koskevia tavoitteita. Politiikan on kuitenkin väitetty kehittyneen yhä itsekkäämpään ja raadollisempaan suuntaan ja valitettavan usein etiikkaa on jopa käytetty täysin omaa tarkoitustaan vastaan taktisena verhoiluna taisteltaessa poliittisesta vallasta (Cowen \& Sutter 2000).

Omaan viestintään kohdistuva itsereflektio on keskeinen osa poliitikkojen viestintäosaamista. Kuten Takala $(1995,45)$ toteaa, tietoisuuden ja itsetiedostamisen hyödyntäminen tilanteissa, jotka koskevat muita ihmisiä, on ensiarvoisen tärkeää ja samalla myös kompetenttia viestintäkäyttäytymistä. Taitava, eettiseen itsereflektioon kykenevä poliitikko pystyy ymmärtämään ja ennen kaikkea perustelemaan omaa toimintaansa ohjaavat ihanteet sekä on sisäistänyt ja pystyy tiedostamaan omaa viestintäkäyttäytymistään ohjaavia ja siihen vaikuttavia arvopäämääriä. Myös Nordenstreng ja Lehtonen $(1998,269)$ korostavat eettisen itsereflektion tärkeyttä poliitikon viestintäosaamisen osaalueena. He toteavat osuvasti, että "viestintä on pehmeä elämän alue, joka on läpikotaisin arvoperäistä ja jonka vastuullinen hallinta edellyttää perusteellista pohdintaa siitä, mikä on oikein ja milkä väärin niïn tiedon hankinnassa, tulkinnassa, käsittelyssä kuin levittämisessäkin".

\section{绉 LOPUKSI}

Tarkastelimme poliitikon viestintäosaamista kolmesta toisiinsa sidoksissa olevasta näkökulmasta. Teoreettisen tarkastelun perusteella viestintä- ja vuorovaikutusosaamisen merkitys poliitikon ammattitaidon ja poliittisen toiminnan kannalta on erittäin suuri. Poliitikon ammattia voidaan myös hyvällä syyllä pitää vuorovaikutusammattina, jossa toiminnan tulokset määräytyvät nimenomaan vuorovaikutuksessa ja jossa onnistuminen riippuu hyvin pitkälti viestintään liittyvien tekijöiden hallinnasta.

Ensimmäiseksi tarkastelimme viestintäosaamista yksittäisen poliitikon henkilökohtaisen viestinnällisen toimintakyvyn, menestyksen ja tavoitteiden saavuttamisen kannalta. Poliitikon näkökulmasta viestintäosaaminen edistää henkilökohtaisia päämäärien saavuttamista, kuten vaalimenestystä tai suotuisan imagon luomista ja ylläpitämistä. Viestintäosaamisen avulla poliitikko voi lisäksi toimia sujuvasti ja tehokkaasti erilaisissa viestintätilanteissa, kuten ryhmissä, neuvotteluissa ja mediassa.

Toiseksi laajensimme tarkastelunäkökulmaa ja pohdimme viestintäosaamisen merkitystä poliitikkojen ja kansalaisten välisen viorovaikutuksen näkökulmasta. Politiikka on jatkuvaa yhteistoimintaa, jossa yhdessä luodaan merkityksiä sekä neuvotellaan, sovitaan ja asetetaan päämääriä, joita kohti pyritään. Pohdimme politiikan olemusta vuorovaikutteisena toimintana, joka määräy- 
tyy ja kehittyy sosiaalisessa kanssakäymisessä ja jonka ytimessä on vallanpitäjien ja kansalaisten välinen luottamus ja yhteistyö. Poliitikolta edellytettäviä vuorovaikutusosaamisen osa-alueita ovat esimerkiksi kyky muodostaa luottamuksellinen, vuorovaikutteinen suhde kansalaisiin sekä kuunnella ja havainnoida yhteiskunnassa tapahtuvia ajankohtaisia asioita.

Lisäksi pohdimme poliitikon roolia yhteiskunnallisena auktoriteettina, joka viestintäkäyttäytymisellään vaikuttaa koko yhteiskunnan toimintaan. Poliitikko on johtaja ja suunnannäyttäjä, jonka on pystyttävä valitsemaan ja muotoilemaan yhteiskunnallisesti arvokkaita ja kannattavia suuntia ja päämääriä. Tämän takia muun muassa johtamisviestinnän ja viestinnän eettisten periaatteiden hallinnan taidot liittyvät läheisesti poliitikon viestintäkompetenssiin. Yhteiskunnallista keskustelua rohkaiseva ja kirvoittava, avoimeen tiedonkulkuun ja vuorovaikutukseen tähtäävä poliitikon viestintäosaaminen lienee yksi demokratian keskeisimmistä perusedellytyksistä ja samalla eräs keskeinen tekijä, joka erottaa demokratian muista hallintomuodoista. Poliitikko yhteiskunnallisena auktoriteettina vaikuttaa paljolti siihen, millaiseksi yhteinen tulevaisuutemme muotoutuu. Siksi kyky pohtia ja reflektoida erilaisia arvopäämääriä ja luoda näköaloja tulevaisuuteen liittyy erittäin keskeisesti poliitikkojen viestintäkompetenssiin.

Näiden kolmen näkökulman kautta kuvastuu se monimuotoinen prosessi, jonka seurauksena yksilöllinen osaaminen sulautuu osaksi kollektiivista sosiaalista todellisuutta. Alkunsa viestintäosaaminen saa yksilön käyttäytymisen tasolta ja heijastuu laaja-alaisesti yhteiskunnallisella tasolla liittyen vallan käyttöön, demokratian toteutumiseen ja etiikkaan.

Keskeinen - ja myös hyvin yllättävä - ero poliitikon ammatissa verrattuna muihin on, ettei siihen ole olemassa selkeitä pätevyysvaatimuksia. Tämän takia on hyvin tärkeää kiinnittää laaja-alaisesti huomiota poliittiseen osaamiseen ja pyrkiä ymmärtämään niitä edellytyksiä, joiden avulla poliitikot voisivat yhä paremmin hoitaa vaativaa tehtäväänsä. Käytännön työssä toimiville poliitikoille tämänkaltainen tieto antaa lähtökohtia oman osaamisen heikkouksien ja vahvuuksien punnitsemiselle sekä tarjoaa mahdollisuuden kehittää omaa ammattitaitoa ja syventää sen erityislaatuun liittyvää itseymmärrystä.

Poliittista pätevyyttä on syytä pohtia myös kansalaisen näkökulmasta. Tietyssä mielessä poliitikon ammatti voitaisiin rinnastaa palveluammattiin, jossa keskeisenä lähtökohtana on asiakkaan, kansalaisen palveleminen. Kansalaiset myös rekrytoivat poliitikot virkoihinsa. Jotta poliittisiin virkoihin valittujen pätevyys voitaisiin varmistaa, tarvitaan tietoa ja ymmärrystä nüstä pätevyyksistä ja osaamisen osa-alueista, joita ammatin vastuullinen hoitaminen edellyttää. Kansalaisen näkökulmasta poliitikon ammattitaidossa korostuvat ainakin useat viestinnän etiikkaan liittyvät seikat, kuten totuudellisuus, avoimuus ja luotettavuus. Kiinnittämällä lisää huomiota poliittiseen osaamiseen voimme tulevaisuudessa mahdollisesti tarjota kansalaisille entistä selkeämmät poliitti- 
sen pätevyyden arviointikriteerit, joiden avulla kansalaiset poliitikkojen työnantajina voivat varmistaa itselleen yhä vastuullisempia ja osaavampia vallan käyttäjiä.

Tarkastelussamme olemme liittäneet toisïnsa yksilökeskeisen puheviestinnän ja yhteisöllisemmän poliittisen viestinnän näkökulmat sekä hahmotelleet poliitikolta edellytettäviä pätevyyksiä nyky-yhteiskunnassa. Tarkoituksenamme on jäsentää paremmin tätä vaikeasti hahmotettavaa aihekokonaisuutta, luoda sille rakenne sekä auttaa eksplikoimaan ja tunnistamaan poliittisen kompetenssin luonnetta ja osatekijöitä. Vaikka tämänkaltainen teoreettinen tarkastelu laajentaa kuvaamme viestinnän merkityksessä politiikassa, se myös saattaa jättää joitakin asioita melko abstrakteiksi ajatusrakennelmiksi vailla käytännön yhteyttä arkipäivän politiikkaan. Tämän takia empiirinen tutkimus sekä konkreettisien esimerkkien ja sovelluskohteiden etsiminen ovat tärkeitä haasteita jatkotutkimukselle.

Kïnnostavaa olisi selvittää, kuinka poliitikkojen ja kansalaisten välinen vuorovaikutus tällä hetkellä toteutuu ja kuinka sitä voitaisiin tehostaa. Tärkeää olisi myös tutkia konkreettisemmin poliitikkojen yksilötason viestintäosaamista esimerkiksi poliitikkojen itsensä näkökulmasta. Miclenkiintoista olisi myös tarkastella sitä, millainen merkitys viestintäosaamisella on poliittisen toiminnan sisällä kuten puolueissa tai vaikkapa hallituksen sisällä ja mikä on sen merkitys suhteessa mediaan ja äänestäjiin. Entä miten nämä sisäinen ja ulkoinen viestintäosaaminen ovat lopulta yhteydessä poliittiseen menestykseen? Toisaalta voisi tutkimuksellisesti tarkastella sitä, onko vuorovaikutteinen, eettinen ja taitava viestintä poliitikolle kannattavaa tai osaavatko kansalaiset sellaista edellyttää, arvioida tai arvostaa.

Lisäksi jatkotutkimuksellinen haaste olisi ylipäänsä poliitikkojen viestintäosaamisen arviointi. Miten olisi mahdollista lähteä arvioimaan tätä laajaa ja monitasoista inhimillisen pätevyyden aluetta? Onko objektiivinen arviointi ylipäätään mahdollista vai onko viestintäosaaminen aina viime kädessä tilannesidonnainen, subjektiivinen ja tulkitsijasta riippuva ilmiö? Millaista on hyvä viestintäosaaminen politiikassa ja miten hyvän viestintäosaamisen tulokset näkyvät? Millaisia arviointikriteereitä poliitikkojen viestintäosaamiselle voidaan asettaa?

Tässä artikkelissa keskeisenä tavoitteenamme oli pyrkiä korostamaan politiikan yhteisöllistä luonnetta ja liittää pohdiskeluun mukaan keskeiset etiilkan, vastuun ja vuorovaikutuksen kysymykset, jotka parhaimmillaan saattavat syventää viestintäosaamisen käsitteen ydinolemusta. Humanistinen, ihmistieteelle tyypillinen pehmeämpi näkemys rikastuttaa kuvaa nykypäivän poliitikosta. Poliittinen pätevyys ei ole pelkästään pelisilmää, tarkkarajaisten strategioiden hallintaa tai oman menestyksen maksimointia vaan yhtä lailla vastuullisuutta, eettistä harkintakykyä, kuuntelutaitoa ja kykyä aitoon vuorovaikutukseen. 


\section{KIRJALLISUUS}

Aristoteles, 1997. Retoriiklka. Runousoppi. Suom. P. Hohti. Helsinki: Gaudeamus.

Cerny, P. G. 1999. Globalization and the erosion of democracy. European Journal of Political Research 36 (1), 1-26.

Cowen, T. \& Sutter, D. 2000. Politics and the pursuit of fame. Public Choice 9 (3), 19-35.

Fishkin, J. 1995. The voice of the people. Public opinion and democracy. New Haven: Yale University Press.

Gerlander, M. 1995. Tavoitteet vuorovaikutuksessa. Teoksessa M. Valo (toim.) Haasteita puheviestinnän opetukseen. Jyväskylän yliopisto. Viestintätieteiden laitoksen julkaisuja14, 51-66.

Gerlander, M. \& Takala, E. 2000. Viestinnän opetus interpersonaalisiin ammatteihin koulutettaessa. Teoksessa M. Valo (toim.) Nykytietoa puheviestinnän opetuksesta. Jyväskylän yliopisto. Viestintätieteiden laitoksen julkaisuja 20, 156-181.

Habermas, J. 1984. The theory of communicative action. Vol 1: Reason and the ratinalization of society. Boston: Beacon.

Habermas, J. 1987. Järki ja kommunikaatio. Helsinki: Gaudeamus.

Isotalus, P. 2000. Tunteita ja reaktioita televisiossa. Ahon ja Halosen nonverbaalinen viestintä. Teoksessa P. Isotalus \& E. Aarnio (toim.) Presidentti 2000. Mistä vaalit on tehty? Jyväskylä: Sophi, 88-105.

Isotalus, P. 2001. Presidential campaigning in Finland and Americanization. World Communication $30(2), 5-23$.

Kaid, L. (toim.) 2004. Handbook of political communication research. Mahwah: Lawrence Erlbaum.

Kegley, C. \& Wittkopf, E. 2001. World politics - Trend and transformation. Boston: MacMillan Press.

Kostiainen, E. 2003. Viestintä ammattiosaamisen ulottuvuutena. Jyväskylän yliopisto. Jyväskylä Studies in Humanities 1.

Littlejohn, S. W. 2002. Theories of human communication. Belmont: Wadsworth.

Lewin, L. 1970. Folket och eliterna. En studie I modern demokratisk teori. Stockholm: Almqvist \& Wiksell.

Mancini, P. \& Swanson, D. L.1996. Politics, media, and modern democracy: Introduction. Teoksessa D. L. Swanson \& P. Mancini (toim.) Politics, media, and modern democracy. An international study of innovations in electoral campaigning and their consequences. Westport: Praeger, 1-26.

Martikainen, T. \& Wass, H. 2002. Laskeva äänestysaktiivisuus sukupolvi-ilmiönä. Politiikka 44, 17-30.

Mazzoleni, G. 2000. A return to civic and political engagement prompted by personalized political leadership. Political Communication 17, 325-328.

Mazzoleni, G. \& Schultz, W. 1999. Mediatization of politics. A challenge for democracy. Political Communication 16, 247-261. 
Nordenstreng, K. \& Lehtonen, J. 1998. Hyvän ja pahan kierrätystä. Viestinnän etiikan perusteita. Teoksessa U.-M. Kivilkuru \& R. Kunelius (toim.) Viestinnän jäljillä. Juva: WSOY, 253-272.

Oulasvirta, L. 2001. Toimiva kunta. Helsinki: Kuntakoulutus.

Paloheimo, H. \& Wiberg, M. 1997. Politiikan perusteet. Helsinki: WSOY.

Palonen, K. 2002. Poliitikon arvostelukyvystä. Politiikka 44, 64-69.

Pekonen, K. 1989. Max Weber. Teoksessa J. Kanerva (toim.) Politiikan teorian moderneja klassikksoja. Helsinki: Gaudeamus, 173-194.

Pietilä, V. 2002. Verkkokeskusteluareenat - deliberatiivista julkisuuttako? Helsinki: Valtiotieteellinen yhdistys.

Putnam, R. D. 1993. Making democracy work. Princeton: Princeton University Press.

Setälä, M. 2003. Voiko poliitikkoihin luottaa? Politiikka 45, 267-268.

Sihvola, J. 1997. Selitykset teoksessa Aristoteles. Retoriikka. Runousoppi. Helsinki: Gaudeamus.

Takala, E. 1995. Näkökulmia tietoisuuden käsitteeseen ja tiedostamiseen puheviestinnässä. Teoksessa M. Valo (toim.) Haasteita puheviestinnän opetukseen. Jyväskylän yliopisto. Viestintätieteiden laitoksen julkaisuja 14, 29-50.

Valkonen, T. 2003. Puheviestintätaitojen arviointi. Näkökulmia lukiolaisten esiintymis- ja ryhmätaitoihin. Jyväskylän yliopisto. Jyväskylä Studies in Humanities 7.

Weber, M. 1949. The methology of the social sciences. Glencoe, Illinois: Free Press.

Weber, M. 1968. Economy and society. New York: Bedminister Press. 